\title{
TINTA KÖNYVKIADÓ
}

Kiss Gábor - Kiss Gyula

A nyelv különös helyet foglal el az emberiség és az egyén életében. Abban majdnem mindenki egyetért, hogy a nyelv az emberiség legnagyobb "találmánya”. Eredete homályba vész. Csak csodálkozhatunk és ámulhatunk, hogy a világ hozzávetőlegesen 4000 nyelvén ki tudjuk fejezni gondolatainkat, érzelmeinket, közölhetjük a legfrissebb tudományos felfedezéseket, és költői alkotásokban mély emberi érzéseket fogalmazhatunk meg.

Nem véletlen, hogy kiemelkedő egyéniségek csodálattal szóltak az emberi nyelvről.

Werner Heisenberg (1901-1976) Nobel-díjas atomfizikus A rész és az egész címú könyvében olvashatjuk a következő gondolatot a nyelv állandóságáról, ugyanakkor hajlékonyságáról is: „Nyelvünknek furcsa, változékony jellege van. Sohasem tudhatjuk, hogy mit jelent egy-egy szó egészen pontosan. Szavaink értelme nagymértékben függ attól, hogy milyen módon rendezzük mondattá öket, és hogy milyen körülmények között beszélünk, és még számtalan hasonló másodlagos tényezőtől. Az atomfizika pedig élesen mutatja, hogy a legmegbízhatóbbnak vélt fogalmaink is csak bizonyos, igen szük korlátok között maradnak érvényben." ${ }^{1}$

A 16. században élt taoista bölcselő, Tu Csi Hsui kiemeli a nyelv közösségi jellegét, hangsúlyozza, megfogalmazza a beszéd „kétirányúságát”: „A beszédem akkor lesz egy velem, ha jóakarattal igazat és fontosat mondok annak, akit megillet." ${ }^{2}$

Bárczi Géza (1894-1975), a 20. század talán legnagyobb magyar nyelvésze így foglalja össze az emberi nyelv fontosságát: „Az emberi elme nagyszerü alkotásai között aligha van még egy, mely alapvetö fontosságban vetekedhetnék a nyelvvel. A nyelv, gondolataink, érzelmeink kicserélésének ez a mindennapi használatú eszköze mindennemü emberi fejlödésnek egyik legföbb tényezője, sőt föltétele. Kétségtelen, hogy a tagolt, hajlékony emberi nyelv az emberiség legnagyszerübb vívmánya, melyet a mai változataiban a nemzedékek végeláthatatlan sorainak állandó eröfeszítése teremtett meg." ${ }^{3}$

\footnotetext{
${ }^{1}$ HEISENBERG, Werner: A rész és az egész: beszélgetések az atomfizikáról. Budapest, Gondolat, 1975.

2 POPPER Péter: Lelkek és göröngyök. Budapest, Saxum, 2005.

3 BÁRCZI Géza: A magyar nyelv életrajza. Budapest, Gondolat, 1975.
} 
Számunkra, magyar anyanyelvűek számára különös jelentősége van a nyelvnek. Bátran állíthatjuk, hogy a magyar nyelv a legnagyobb hungarikum. Ezt bizonyítják a következő állítások a magyar nyelvről: 1. nemzeti kultúránk legfőbb hordozója; 2 . a nemzet memóriarendszere; 3 . kollektív tudat; 4 . összetartó, nemzetmegtartó erő.

Nem véletlen, hogy magyar anyanyelvünkkel kapcsolatban képszerű metaforákkal élünk. PI.: az anyanyelvünk: 1 . édesanya (szeretni való, kedves, egyetlen); 2 . kincs (féltett, őrzendő); 3. erős vár (összetartó erő, védelmet nyújtó); 4. kert (burjánzik, nyesegetni és ápolni kell); 5. gépezet (kopik, romlik).

Közismert, hogy a nyelv két nagy részből áll. Egyrészről „építőkockák” halmazából, amelyek a nyelv minden szintjén jelen vannak. Ezek a hangok, morfémák, szavak és szókapcsolatok. Másrészről a nyelv „építési szabályok” sorából áll, ez a nyelvtan, amely megmondja, hogy a gazdag építőelem-készletből miként rakhatjuk egymás mellé az építőelemeket.

Kétségtelen tény, hogy a nyelv építőkocka-készletének központi és legfontosabb eleme a szó. Nem véletlen, hogy maga a „szó” több mint kétszáz magyar szólásban szerepel. PI.: állja a szavát; szaván fogják; elakad a szava; egyik szavát a másikba ölti; szavahihető ember; szót fogad; szavakon lovagol; az utolsó szó jogán.

A Tinta Könyvkiadó épp ennek a központi nyelvi elemnek, a szónak leltározását, szótárakba foglalását tűzte ki célul és végzi következetesen több mint két évtizede. A Tinta Könyvkiadó magyar tulajdonú, budapesti székhelyű szótár- és nyelvészeti szakkönyvkiadó. Évente 30-40 nyelvészeti szakkönyvet és 6-8 saját fejlesztésű magyar szótárt ad ki. Napjainkban a magyar egynyelvű szótárkiadás piacvezetője.

A kiadó magas színvonalú munkásságát számos szakmai elismerés, kitüntetés bizonyítja: Budai-díj, könyvtárosok Fitz József-könyvdíja, Lőrincze Lajos-díj, MTA „Kiváló Magyar Szótár" díj, Pro Cultura díj, Szép Magyar Könyv Oklevél.

A Tinta Könyvkiadó mélyen beágyazódott a magyar tudományos életbe, több mint 2500 nyelvészt tudhat szerzőjének. A kiadó szerzői, munkatársai a hazai nyelvészet elismert szakemberei, többen az MTA tagjai, illetve doktorai. A szerzők közül számosan az MTA Nyelvtudományi Intézetének munkatársai, illetve egyetemi tanszékek, kutatóhelyek vezetői. Széles körű szakmai kapcsolati hálót épített ki az elmúlt két évtizedben. Többek között együttmúködő szakmai partnerei: Magyar Alkalmazott Nyelvészek és Nyelvtanárok Egyesülete (MANYE), Anyanyelvápolók Szövetsége (ASZ), ELTE BTK Mai Magyar Nyelvi Tanszék, Erdélyi Anyanyelvápolók Szövetsége, Magyar Könyvtárosok Egyesülete, Magyar Nyelvi Szolgáltató Iroda, Modern Filológiai Társaság, MTA Titkársága, MTA Nyelvtudományi Intézete, MTA Szótári Munkabizottság, Vajdasági Magyar Szövetség. 
A Tinta Könyvkiadó szótárairól, nyelvészeti kiadványairól rendszeresen elismerő recenziót közölnek a szakfolyóiratok (Magyar Nyelv, Magyar Nyelvőr, Nyelvtudományi Közlemények, Modern Nyelvoktatás, Anyanyelv-pedagógia), és az új kiadványok megjelenéséről beszámolnak a magyarországi napilapok és hetilapok. A kiadó nyelvészeti és szótársorozatai a következők: A magyar nyelv kézikönyvei (1-31.); Segédkönyvek a nyelvészet tanulmányozáshoz (1-215.); Az ékesszólás kiskönyvtára (1-72.). A sorozatok folyamatosan újabb tagokkal bővülnek.

A Tinta Könyvkiadó két honlapjáról (http://www.tinta.hu, http://www.tintakiado.hu) tájékozódhatnak a kiadóban folyó kutatásokról, munkálatokról, eredményekról az érdeklődők. A kiadó működteti és tölti fel rendszeresen tartalommal az Anya-nyelv-csavar blogot (https://anyanyelvcsavar.blog.hu)

A Tinta Könyvkiadó jelentősebb egynyelvű nagyszótárai közé tartozik a Magyar értelmező diákszótár, a Magyar szókincstár, a Magyarító szótár, az Etimológiai szótár, az Értelmező szótár, a Nyelvművelő kéziszótár, a Magyar szólások, közmondások értelmező és fogalomköri szótára és az Idegenszó-tár.

A SzóTudásTár létrehozását a Tinta Könyvkiadóban két évtized alatt összegyúlt és felhalmozott jelentős nyelvészeti, lexikográfiai, szótárírói tapasztalat tette lehetővé. A SzóTudásTár a leggazdagabb tartalmú, interneten elérhető egynyelvű magyar szótár, amely a magyar szavakról a következő témakörökben ad információkat: helyesírás; értelmezés, jelentés; szinonima; eredet, etimológia; ellentét; szólás; közmondás; idegen szavak jelentése, eredete; régi szavak jelentése, eredete; kiejtés; összetett szavak; szólások, közmondások eredete.

A SzóTudásTárban elérhető több mint tíz, a témában piacvezető szótár tartalma, és a szótárakból a bőség miatt kimaradt további szócikkek, összesen több mint 500 ezer nyelvi adat, ezzel a leggazdagabb tartalmú magyar nyelvi tudástár.

1. táblázat. A SzóTudásTár 11 nagyobb szótári adatbázisa és az egyes szótári adatbázisok címszavainak a száma

\begin{tabular}{|l|c|}
\hline \multicolumn{1}{|c|}{ Szótár } & Címszavak száma \\
\hline Értelmező szótár & 15853 \\
\hline Etimológiai szótár & 8900 \\
\hline Szinonimaszótár & 25796 \\
\hline Ellentétszótár & 13636 \\
\hline Régi szavak szótára & 19378 \\
\hline Kiejtési szótár & 30922 \\
\hline
\end{tabular}




\begin{tabular}{|l|c|}
\hline Összetett szavak & 56843 \\
\hline Magyarító szótár & 12652 \\
\hline Idegen szavak szótára & 27464 \\
\hline Szólások, közmondások szótára & 14163 \\
\hline Rövidítések szótára & 12074 \\
\hline
\end{tabular}

A felület letisztult, egyszerü, felhasználóbarát, a kisiskolásoktól a legidősebbekig minden korosztály kényelmesen kezelheti. A SzóTudásTár elérhetővé tehető bármely internetes kapcsolattal rendelkező eszközön, számítógépen, tableten, okostelefonon. A legmodernebb és elterjedt technológiák, informatikai megoldások kerültek felhasználásra a fejlesztés során (PHP, MySQL, AJAX, XML, JQuery, JSON, MooTools, HTML5). A keretrendszer telepítése új szerverre nem igényel különösebb erőforrást.

1. ábra. A SzóTudásTár belső reprezentációja I.

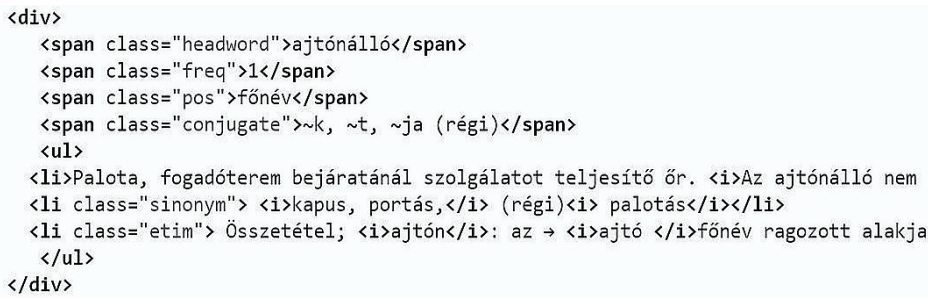

2. ábra. A SzóTudásTár belső reprezentációja II.

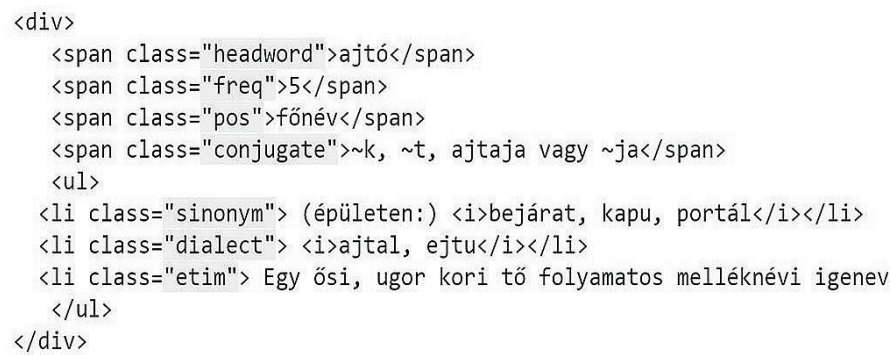

A SzóTudásTár alkalmas a kisiskolások internetes szótárhasználatra nevelésére, segítségével hiteles forrásból kereshetik ki azt, amit tudni szeretnének a magyar szavakról, ezzel fejlesztve nyelvi kifejező- és értelmezőkészségeiket. A SzóTudásTárban a kötelező olvasmányok régies szavai mind megtalálhatóak. Célközönség még a felsőbb fokon tanulókon túl az iskolát már elvégzett munkavállalók is, hogy például elkerülhessék a szóismétlést, vagy kikereshessék egy idegen szó jelentését. Mindezek mellett nagy segítség magyar nyelvet tanulók számára is. 
A SzóTudásTárban minden egyéni és összesített keresés mérhető, elemezhető és felhasználható nyelvi-nyelvészeti kutatásokhoz, a nyelv változásának vizsgálatához.

A SzóTudásTár hiteles forrás és hivatkozási alap. Az interneten elérhető más tartalmak, szótárak nagy része nem lehet forrás és hivatkozási alap, mert hitelességük megkérdőjelezhető. Ennek további bizonyítéka, hogy a kiadónak dolgoznak a mai nyelvész, szótárszerkesztő társadalom legnagyobbjai, többek között: Grétsy László magyar nyelvész, nyelvmúvelő, Bárdosi Vilmos, az ELTE BTK Romanisztikai Intézetének munkatársa, Kiss Jenő akadémikus, Tótfalusi István nyelvész, műfordító, szerkesztő.

3. ábra. A SzóTudásTár keresőfelülete

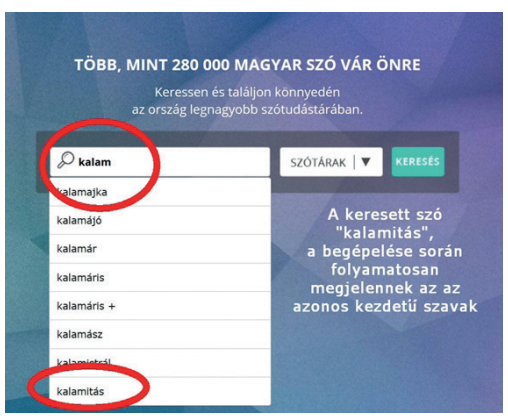

A SzóTudásTár oldal innovatív, folyamatosan bővül és fejlődik. A Tinta Könyvkiadó szerkesztői csapata folyamatosan fejleszti a szótárakat, készíti az új szócikkeket. Ennek módja többek között az új szavak, "divatszavak" keresése például újságokban, másrészt a szótárakban még nem szereplő szavak regisztrálása. Sok más országban a SzóTudásTárhoz hasonló tartalmú internetes, modern, egynyelvú szótárakat állami irányítással fejlesztik és szolgáltatják, költségvetési vagy európai uniós forrásból. Magyarországon ez nem történt meg, ezt pótolja a SzóTudásTár.
4. ábra. A SzóTudásTárban a kalamitás szó találati listája

Az utóbbi év jelentős fejlesztésének eredményeképpen lehetőség nyílt arra, hogy a SzóTudásTár használói ne csak az adatbázist alkotó szócikkek címszavaira keressenek, hanem a szócikkek belsejében lévő szavakra is. Ezt a lehetőséget a keresőfelületen lévő kapcsoló beállításával lehet elérni.

Meggyőződésünk, hogy Kosztolányi Dezső, aki a szótárakról az alábbi magasztos sorokat írta Szótárt lapozgatok című írásában, még nagyobb csodálkozásának adott volna hangot, ha használhatta volna a TINTA Könyvkiadó SzóTudásTárát:

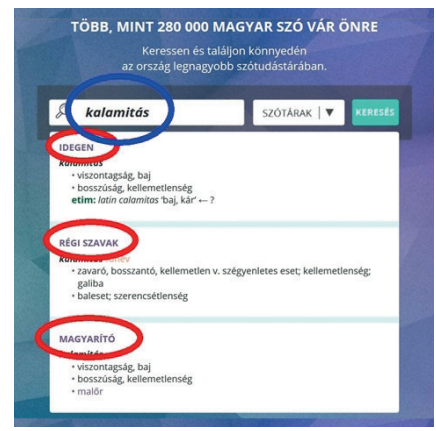

„Szótárat lapozgatok. Van-e a szótárnál gazdagabb, élőbb, lelkesebb valami? Benne van nyelvünk összes szava. Benne van a virágok, ásványok, rovarok, háziállatok és fenevadak, a szerszámok, a közlekedési eszközök és fölszerelések, a fegyverek és hangszerek, a mesterségek, a testrészek és a nyavalyák neve. Benne van a gyöngédség és a durvaság 
minden árnyalata, az udvariasság és a gorombaság, a szemérem és a trágárság, a szépség és a rútság, az illat és a büz, a tisztaság és a szutyok, a boldogság és a boldogtalanság, az önfeláldozás és a gyilkosság. Benne van a múltam, a jelenem és a jövendöm. Benne van az életem. Benne van a halálom is. Benne van a sorsom." ${ }^{4}$

A SzóTudásTár mellett a SzakKönyvTár a kiadó utóbbi több mint húsz évben megjelent szakkönyvtermését tartalmazó adatbázis. Elérhető benne a Tinta Könyvkiadó Segédkönyvek a nyelvészet tanulmányozásához sorozatának 210 kötete és 40 további szakirányú kiadvány. Társadalomtudományi, főként nyelvészeti, kommunikációtudományi szakkönyvek gyűjteménye. Ezeket a társadalomtudományi monográfiákat, tanulmányköteteket és konferenciaköteteket a legtöbb magyarországi felsőoktatási intézményben használják. Az adatbázis több mint 1500 szerző munkáját tartalmazza. A szakkönyvek szerzői a Magyar Tudományos Akadémia intézeteinek munkatársai, az ELTE, a Debreceni Egyetem, a Szegedi Tudományegyetem, a Nyíregyházi Egyetem, a Pécsi Tudományegyetem és más egyetemek, főiskolák oktatói, kutatói. Az adatbázis év közben is folyamatosan frissül az újonnan megjelenő szakkönyvekkel. Az IP-alapú szolgáltatás mellett eduID-alapú azonosítással is használható a szaktars.hu felületén.

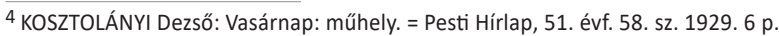

